\title{
12. Care for older people in three Mediterranean countries: discourses, policies and realities of de-institutionalisation
}

\author{
Blanca Deusdad, Sagit Lev, Charles Pace and \\ Sue Vella
}

\section{INTRODUCTION}

This chapter seeks to shed light on de-institutionalisation and the way people are 'ageing in place' in Mediterranean countries, based on case studies developed in the context of the COST Action IS1102 SO.S. COHESION - Social services, welfare states and places. Israel, Malta and Spain are chosen to represent diversity in size and demography, but also in culture, religion, history and sociopolitical context. De-institutionalisation can be defined as a policy emphasising care in or by the community rather than care within an institution, but it also refers to the prevention of institutional placements (Bachrach, 1976). Although the de-institutionalisation movement was mobilised by criticism addressed at mental health institutions, it expanded to also include the care of older people, children and persons with disabilities (Lerman, 1985; EEGTICC, 2012). The concomitant need for an expansion of appropriate community-based services makes de-institutionalisation an important object of study (Bachrach, 1976; Fakhoury and Priebe, 2007; EEGTICC, 2012).

De-institutionalisation of care for older people has been studied in the Nordic, Central and Eastern European countries (Deusdad et al., 2016a), while little is known about how this process has played out in Mediterranean countries (Deusdad et al., 2016b; Pace et al., 2016), in spite of the fact that de-institutionalisation is a subject of the Common European Guidelines (EEGTICC, 2012). Looking at the three Mediterranean countries one notices, first, that the share of older people in institutions has been low, particularly in Spain, compared to other European countries. Second, there are differences as to how far there has been a clear policy 
discourse fostering de-institutionalisation or ageing in place. Third, deinstitutionalisation in the three countries has not been a homogeneous process. Its implementation has varied in extent and even, one can say, in its validity, where insufficient resources raise the question of whether it might have amounted to a false de-institutionalisation policy.

The first section of this chapter focuses on the relevant research and literature, the next three sections describe the situation in the three countries and section 5 reflects on similarities and differences among these countries with respect to the policies and discourses on de-institutionalisation and ageing in place.

\section{SHIFTS OF CARE AMONG INSTITUTIONS, FORMAL COMMUNITY SERVICES AND FAMILY}

De-institutionalisation is a widely used concept and policy option. Preference for de-institutionalised care, even where care needs are extensive, is grounded in the belief that living in the community protects those fundamental human rights that institutional care might deny (Ilinca et al., 2015). This is reminiscent of the concept of the total institution, coined by Erving Goffman (1968) to refer to 'a place of residence and work where a large number of like-situated individuals, cut off from the wider society for an appreciable period of time, together lead an enclosed, formally administered round of life' (Goffman, 1968, p. xiii). Researchers have identified these features as applying to a considerable extent to typical institutions for older adults (Lang et al., 2007; Thomas, 2004), exerting pressure for conformity and obedience (Solomon, 2004) through a functional efficiency begetting rigid routines, low privacy and autonomy, and limited choice (Angelelli, 2006; Harnett, 2010).

In respect of the elderly, de-institutionalisation aims to promote ageing in place, defined as 'remaining living in the community, with some level of independence, rather than in residential care' (Davey et al., 2004, p. 133). Ageing in place requires services and facilities to be located close to the homes of older adults, affordable and known to potential users through clear information (WHO, 2007).

The philosophy of ageing in place is underpinned by the European Union's Charter of fundamental rights, which declares that 'The Union recognises and respects the rights of older adults to lead a life of dignity and independence and to participate in social and cultural life' (European Parliament, 2010). To simply reduce beds in institutional care is, by contrast, more about cost reduction than about the best interests of older adults (EC, 2008). Evaluation of ageing in place should look into the 
adequacy of services available in the local community (Bachrach, 1976; Fakhoury and Priebe, 2007). Adequate community-based services, including home-based care, all facilitate ageing in place through different means (Doyle and Timonen, 2007; Lehmann and Havlíková, 2014). Such services provide the support which older adults need and which enable them to participate in everyday life (EC, 2008).

Community care is taken, in the usual British sense, to refer to care given to people while they live 'in the community', normally at home (even when they go to outpatients' hospitals to receive care). Home care or domiciliary care refers to care received at home, for example 'meals-on-wheels' and home help. In many contexts, the concepts of community care and home care are not distinguished. Living in home-like and 'not-so-total' small shared residences is often not referred to as institutional care (Moise et al., 2004).

Preference for community-based over institutional care is supported by an increasing body of evidence to the effect that the former generally provides better results for users, families and staff, at comparable cost (EC, 2008). Furthermore, most Europeans perceived ageing in place as the best care for older adults (European Commission, 2007). Developing different forms of community to improve living conditions of older adults also involves reinforcing and enlarging social networks at the neighbourhood level.

Still, recent evaluations have questioned the universal appropriateness of ageing in place, the success of which is linked to the degree of disability and the type of available services (Grabowski, 2006; Mansell et al., 2007; Wysocki et al., 2015). Thus, where 24-hour care is needed, institutions may be preferred (Fakhoury and Priebe, 2007), but there is of course a need to create residences that are 'less institutional' by being small and more home-like. This need is reflected in the cultural shift from a medical and institutional model to a client-oriented model with home-based features (Kane and Kane, 2001; Koren, 2010; Thomas, 2004), and being part of the wider community rather than separated from it (Rabig et al., 2006; Thomas, 2004).

In this chapter de-institutionalisation is studied in a Mediterranean context. A number of welfare state researchers contend that Southern European or Mediterranean countries are a distinct welfare regime with unique characteristics (Damiani et al., 2011; Ferrera, 1996; Leibfried, 1992; Rhodes, 1996). Gal (2010) extended the Mediterranean regime to include the islands of Cyprus and Malta, as well as Turkey and Israel in the East (a cluster admittedly considered too broad by Guillén and León, 2011; see also Pace, 2009).

While acknowledging differences among Mediterranean countries' 
social policies, religion, cultural heritage, social conditions and standards of living, Gal $(2009 ; 2010)$ claimed that they shared enough common features to distinguish them from other European regimes. Common shaping factors were a history of late industrialisation linked to lingering non-democratic or colonialist regimes as well as strong influence of religion, family and clientelistic networks. All this contributed to a common pattern of a relatively weak welfare and economic system (Gal, 2009; 2010) and a family that is strongly relied upon for care, often involving resource pooling and soft budgeting by the household or extended family (Moreno, 2000; Petmesidou, 1996).

Family care is thus prominent in Mediterranean countries, where women are expected to take responsibility for the care of older relatives. Israel, Malta and Spain, as other Mediterranean countries, also feature large numbers of home-based migrant women care workers, often hired by families from within the low-paid black economy, a common Mediterranean trend (Torrens-Bonet, 2012; Vara, 2014).

Like most of Europe, Mediterranean countries experience processes of restructuring, marketisation and promotion of choice (Deusdad et al, 2016a; Mathew-Puthenparambil and Kröger, 2016; Moreno-Fuentes and Mari Klose, 2015). These processes have deeply influenced the deinstitutionalisation of care for older people aimed at ageing in place, as expressed in EU guidelines and social workers' discourse. The 2008 economic crisis, affecting Mediterranean countries in different ways, has in its turn widely provoked restructuring and, for instance, in the case of Spain has affected the implementation of long-term care (LTC) policy (Deusdad et al., 2016b).

This chapter focuses on Israel, Malta and Spain, with the aim that this study of similarities and differences may help shed light upon the deinstitutionalisation of care in the Mediterranean welfare regime in a time of economic crisis. The selection of the three countries emerged from their geographical spread across the Mediterranean (Israel in the East, Spain in the West and Malta in the centre), their different population size and also their largely varied historical roots. Furthermore, while Portugal, Spain, Italy and Greece are most often studied, we felt it important to include Israel and Malta which, though seen by Gal as Mediterranean regime countries, are studied far less often. Meanwhile, statistics in Table 12.1 set the scene through some comparisons.

De-institutionalisation and ageing in place policies will be compared in the light of each country's legislation, formal and informal care systems, processes of marketisation or privatisation, family strategies and other changes in the face of the economic crisis. Through the three country case studies and the subsequent comparative discussion, we shall be addressing 
Table 12.1 Selected comparative data for Israel, Malta and Spain

\begin{tabular}{lccc}
\hline Indicator & Israel & Malta & Spain \\
\hline Percent of population aged $\geq$ 75 in 2015 & $4.89^{1}$ & $7.41^{2}$ & $9.23^{2}$ \\
Old-age dependency ratios (persons aged $\geq 65 /$ & $15.7^{3}$ & $21.4^{2}$ & $24.6^{2}$ \\
$\quad$ persons aged 15-64) & & & \\
Number of persons in the population aged $\geq 65$, & $46.0^{7}$ & $18.0^{10}$ & $24.0^{10}$ \\
$\quad$ per available bed in nursing \& residential & & & \\
$\quad$ facilities & & & \\
Life expectancy for men aged 60 in 2013 & $23.3^{5}$ & $22.5^{4}$ & $23.1^{4}$ \\
Life expectancy for women aged 60 in 2013 & $25.7^{5}$ & $25.9^{4}$ & $27.9^{4}$ \\
\% of GDP spent on welfare (2013) & $10.9^{8} 0^{8}$ & $18.5^{7} 0^{7}$ & $25.2^{\%}$ \\
Long-term care expenditures as a \% of GDP & $0.4^{6}$ & $1.1^{9}$ & $1.0^{9}$ \\
& $(2010)$ & $(2013)$ & $(2013)$ \\
\hline
\end{tabular}

Source: Authors' elaboration based on 1) Central Bureau of Statistics - Israel (2016a; 2016b; 2016c); 2) Eurostat (2016a); 3) Central Bureau of Statistics - Israel (2016a); 4) Eurostat (2016b); 5) OECD (2016a); 6) OECD (2016b); 7) Eurostat (2016c); 8) Central Bureau of Statistics - Israel (2016b; 2016c); 9) European Commission (2015); 10) Eurostat (2016d).

- with varied levels of intensity - the following three questions that articulate our underlying conceptual framework: (1) How far were the discourses of deinstitutionalisation and ageing in place embraced in actual policy strategies? (2) Which older adults are considered to require institutionalisation? (3) To what extent have policy discourses and strategies corresponded to reality?

\section{THE CASE OF ISRAEL}

In Israel in 2014, persons over 65 accounted for 11 per cent of the general population. Most older adults in Israel lived in the community, while approximately 3 per cent lived in LTC institutions (Brodsky et al., 2015).

Institutional care of the older population in Israel is under government responsibility, while financing and regulation are shared between the Ministry of Welfare and Social Affairs, responsible for semi-independent and frail older adults, and the Ministry of Health, responsible for severely disabled older adults. These services are means-tested. The government is also responsible for home-based care, provided mainly by the Ministry of Social Affairs and Social Services (Azary-Viesel and Stier, 2014).

Another significant resource for older people in Israel is the National Insurance Institute (NII) (Bituach Leumi). According to the NII Law of 
1995, two major allowances are available: the old age benefit, paid monthly on a universal basis to each insured person after retirement, and long-term care benefit, supporting services to older persons needing assistance and supervision in their daily functioning in the community (Azary-Viesel and Stier, 2014; Borowski, 2015). The cash benefits from the social security system pertaining to older adults in Israel comprise four layers. The two first layers are provided by National Insurance (NI) and include universal old age benefit (which was mentioned earlier) and selective financial support for older adults who need it. The third level includes work-related pensions. Finally, the fourth layer includes retirement saving ( $\mathrm{Gal}$ and Pesach, 2002).

The most significant expression of de-institutionalisation of older people in Israel is the Long-term care insurance programme (LTCIP) (Bituach Seeood). We shall first briefly describe the background and the causes for the enactment of the LTCIP and the services that are included in it. Then we will focus on challenges facing the programme, since its enactment, relating to de-institutionalisation. LTCIP, administered since 1968 by National Insurance, promotes in-kind services for frail older people living at home (Iecovich, 2012), one of its goals being the reduction of demand for residential care (Borowski, 2015; Iecovich, 2012). Prior to the implementation of LTCIP, most services for older people were provided by the social assistance system. Limited in their scope, these were given mostly to poor older adults on a discretionary basis. Older adults who were ineligible for home-based services applied for publicly subsidised institutional care. Since the 1970s, the necessity arose for wider and more adequate resources, due to four main factors: (a) the enormous gap between the needs of the frail older population and the assistance available; (b) high cost of institutional care; (c) actual and predicted growth in the older population; and (d) a growing official recognition of the implications of the burden of care borne by family caregivers. In light of these needs, LTCIP was enacted in 1986, aiming to provide in-kind benefits for frail older adults through an array of personal care and homemaking services, and to enable 'ageing in place', alleviating the family caregivers' burden and reducing national expenditure on institutional care (Borowski, 2015; Borowski and Schmid, 2001; Iecovich, 2012; Schmid, 2009; Schmid and Borowski, 2004). Eligibility for LTCIP requires applicants to be Israeli citizens living in Israel and over the official age of retirement (age 64 for women and 67 for men). Applicants must be mentally and/or physically frail and in need of assistance or supervision with daily activities. They must live in their home in the community or in continuing care retirement communities and undergo an income test. The latter is quite generous and a vast majority meet these income criteria (Iecovich, 2012). Most promi- 
nent within LTCIP is home care, ranging from 9.75 to 18 hours per week (Borowski, 2015). Other services include daycare centres, alarm systems, laundry services and free incontinence pads (Iecovich, 2012).

A study that compared the patterns of institutionalisation prior to the implementation of LTCIP with those of several years later found a reduction of 25 per cent in the number of older adults in residential care. Additionally, the composition of the applicants for residential care changed. They were older, more disabled and more likely to have been widowed (Naon and Strosberg, 1996). However, the future of this deinstitutionalisation in the context of LTCIP is less certain and further research is necessary to further explore this process (Asiskovitch, 2013; Borowski, 2015). Despite a significant increase in community-based assistance to older people, its coverage is still partial. The concept underlying this policy is providing a moderate degree of aid to a larger number of beneficiaries, rather than providing comprehensive assistance to a more limited number (Ben-Zvi, 1990). This policy also draws upon the values of Israeli and Jewish society, emphasising the involvement and the responsibility of family members in the care of older relatives (Iecovich, 2003). However, when there is need for institutional care, the government, through the Ministry of Health and the Ministry of Labour and Social Affairs, can provide full funding after an income test of the older adult and their children (Brodsky et al., 2003).

Thus, although the move of the older person to institutional care is often a result of decline in health or functional ability, in some cases the transition can occur due to a shortage in the economic or social resources of the older person and their family. This difficulty could worsen due to current processes of privatisation and liberalisation in Israel (Doron, 2007) alongside changes in family structure, mainly reflected in the growing participation of women in the labour market (Lavee and Katz, 2003; Toren, 2003). Thus women, who carry most of the informal caregiving responsibility, are left with less time and fewer resources to support older family members (Iecovich, 2003). Although amendments and adjustments in LTCIP have occurred over the years (Asiskovitch, 2013), these changes pose new challenges to LTCIP and to the continuation of the de-institutionalisation process in Israel.

\section{THE CASE OF MALTA}

Malta's population of 420000 is one of the fastest-ageing in the EU-28, flagging serious challenges for the future, even if the constant rise of GDP in recent years should enable the growth and not necessitate the reduction 
of services. By 2030, the over-65s and the over-80s will make up 25 per cent and 8 per cent respectively of the population.

Since the mid-1980s, discourse has been led by the terms 'community care', 'remaining in one's community' and, lately, 'ageing in place', though 'primary care' has also lingered longer than strictly appropriate as a competing term within health services vocabulary. Outside mental health, de-institutionalisation - taken to mean moving older people out of institutions - has not been a key goal in Maltese policy. The exception was the optimism that marked the newly-formed junior ministry for the elderly around 1987, which aspired to make such moves out of the state's 1000+ bed institution. This proved to be a short-lived dream amid the then undeveloped community services and residents' reluctance to relinquish their prized places in the institution.

Maltese expectations of care in old age by family or institutions exceed European averages: 53 per cent of Maltese (but 45 per cent in the EU) expect care at home by a relative. This is a tradition with a diminishing future, as Malta's female employment rate - while low - is the fastest-rising in Europe. Maltese are less than half as likely as other Europeans to expect to be cared for at home by a formal carer, while one in five Maltese (more than twice the EU average) expect to receive institutional care (European Commission, 2007).

The bulk of Malta's public expenditure on LTC goes into residential institutions. Specific cash benefits for LTC do not exist in Malta, and state home-based care costs amount to less than 0.1 per cent of GDP, as opposed to 0.53 for EU-27 in 2010 (European Commission, 2012). Meanwhile, government encouragement of 'ageing in place' has not been matched by a progressive growth of community services. There has been underinvestment in social work, disregarding its potential to improve support and survival in the community.

No law caters specifically for the care of older adults, although an Active Ageing Strategy has been in place since 2013. In Malta, welfare provision is within the capacity of only one tier of government, and its development is frequently driven by ministerial executive action, without the support of specific legislation beyond the Budget Act. Means-tested old age pensions were introduced in 1948, followed in 1956 by a contribution-based system. Since 1979, Malta has had a mandatory earnings-related contributory pension targeted to provide a pension equivalent to two-thirds of the average earnings of the insured person. However, due to a long frozen pensionable earnings cap, this objective has become a progressively rarer attainment in reality. Those who do not meet eligibility criteria for an NI pension can benefit from the non-contributory scheme as long as they satisfy conditions of residency and financial means (both income and 
capital assets of household members). While there is no LTC allowance as such, public residential care is usually paid by withholding about 70 per cent of one's state pension at source.

Residential care accommodation is now of four broad types: purely statutory; purely church; purely private; and public-private initiatives, including 'bed purchasing' by government. State hostels, started in the late 1980s for the able-bodied, have since become nursing homes. As far as community services are concerned, 1987 saw the growth almost from scratch of home care (meals-on-wheels, home helps, handyman, alarmtype Telecare) and, later, daycare. All this has increased in volume, only to reach a plateau in the last decade.

A significant move has been made to outsourcing. Public-private partnerships have been the declared path to increasing bed availability, through building and running new homes for older persons on the one hand, and publicly paid beds in private homes on the other. In 2015, the government transferred the provision of two key services (home nursing and meals-onwheels) from NGOs to a for-profit provider (Pace et al., 2016). It is too early yet to assess the managerial, political and ideological significance of this little-discussed move. While no notable cuts have taken place, government provision has not kept pace with growing need. This has led to 'privatisation by default' or 'passive privatisation', through increasing recourse to private paid care (especially residential), to home-based care by immigrant care workers or, least likely, to community support.

Strikingly, populations in state-run residences have grown by 4 per cent a year since 2008, while use of the main home care services has barely grown at all. Similarly, the budget for residential care since 2006 has grown six times faster than that for community services. Clearly, community care growth has been deeply impeded by insufficient investment, although efforts are being made. A scheme to lighten residential waiting lists through subsidising home-based care workers was piloted in 2016, and has been extended into 2017. The budget for 2017 also includes a significant increase in the Carer's Pension and Carer's Allowance, payable to those caring for persons with high or medium dependencies in their own home.

A potentially positive move has been the transfer in 2013 of community care from the Health to the Social Solidarity ministry. The opportunity to correct the narrow view of the medical and institutional model at the expense of a social support model that could reduce recourse to residential care should not be lost. Yet, for a population of about 100000 persons aged over 60 , there are still only six social workers working in the community. These social workers play an important role in assessments, and as gatekeepers to home and residential services. The demands on their time 
result in an emphasis of quantity over quality while their potential to finetune care networks and prevent overuse of residential care is wasted.

The major challenges now, in order not to be overwhelmed by the fastapproaching demographic growth in dependency, are to study the lessons of international good practice, to robustly expand the needed resources for effective community care, to espouse its holistic and especially its social dimension, and to expand social work to develop the support capacities of local networks. Additional challenges are to develop a philosophy of community care overarching the care of older, disabled and mentally challenged persons and to introduce a flexible case management system (Pace, 2002) to achieve the necessary care programming and interagency coordination that makes best use of finite resources.

\section{THE CASE OF SPAIN}

In Spain, persons aged 65 and over represented 18.1 per cent of the total population in 2014 and this is increasing with the ageing of the babyboomer generation. Those over-65 in care homes (residencias asistidas) account for 2.8 per cent (Imserso, 2014). The social services system in Spain has largely developed during the 1980s after the arrival of democracy. Pensions are the most important income for older adults, and in the Spanish case are particularly relevant because of their incidence in family solidarity strategies as we will explain later on. The Spanish pensions system is a mixed system, with contributions by workers and companies towards contributory pensions (pensiones contributivas). The state also provides non-contributory pensions (pensiones no contributivas). Older adults are eligible for a pension, although there are important gender differences, due to the fact that during Franco's dictatorship married women were forced to resign.

While pensions are low but assured, there is no specific Spanish social policy on the care of older people. Nevertheless, 1 January 2007 saw the promulgation of the Law 39/2006, for the promotion of personal autonomy and care for elderly people and disabled people (Ley de Promoción de la Autonomía Personal y Atención a las personas en situación de dependencia, henceforth LAPAD), which is a state social service law, common for all regions (Comunidades Autónomas). Its main objective was to improve living conditions of dependent people of all ages, including people with physical or mental disabilities and for frail older adults dependent on help in doing Activities of Daily Life (ADL) (Deusdad et al., 2016b; see Deusdad, Javornik et al., in this volume; Hidalgo-Lavié and FernándezSanz, 2010; Vilà, 2011). 
LAPAD provides a choice between three benefits:

- Cash transfers to purchase services, with a choice among Telecare, day centres, residential and home care.

- An anticipated service-linked benefit (Prestación vinculada al servicio) for people assessed as having a degree of dependence and wanting to be in a care home. The regional administration gives a cash transfer to enable the advance payment of residential care. This measure was suspended during the peak of the 2008 crisis. Other cash transfers for buying technical equipment and adapting homes are also granted.

- An allowance for family care (Prestación económica para cuidados en el entorno familiar), or for hiring a personal assistant. This last option has almost never been implemented, except in the case of the Basque Country (Deusdad et al., 2016b).

Overall, though LAPAD was not intended to be a de-institutionalisation policy, it indirectly affected the way ageing in place played out in Spain. However, the implementation of LAPAD fell victim of the economic crisis. Major austerity measures were implemented: two Royal Decrees, 20/2011 and 20/2012, imposed cutbacks on LTC at the State level, whereby the full implementation of this law was postponed and the benefits for family care reduced (see Deusdad, Javornik et al., in this volume).

Even though the law considered the allowance for family care an 'exceptional measure', it has been implemented since 2007 in ways that gave it a deep nationwide presence. Older adults with extensive care needs have remained at home under the supervision of family carers, instead of being institutionalised. This was especially reinforced due to the economic crisis. Families could not afford assisted living facilities solely relying on retirement pensions. Moreover, in situations of unemployment and mortgage debt, living under the same roof as older adults became a way of saving money, enabling relatives to use the older adults' pensions as a source of income (Deusdad et al., 2016b). Added to this there were long waiting lists due to increasing delays between applying for and receiving these benefits, often taking years, by which time the applicant might have died. All this intensified reliance on family care.

Concluding, LAPAD, which introduced the allowance for family care, was not aimed at promoting 'ageing in place' as such, but at reducing public spending and at meeting users' and their families' preferences. However, due to both the actions of implementing administrators and people's agency, the law ended up leading to a false ageing in placeldeinstitutionalisation policy and reinforcing re-familisation (Deusdad et al., 
2016b; see the notion of 'passive' re-familisation in Leibetseder et al., in this volume). Ageing in place in Spain is, then, not a clear and intended social policy goal but mainly the unintended result of scarcity of resources and of high rates of female and male unemployment, which have pushed different generations back to living together and to relying on family care.

\section{DISCUSSION, COMPARISON AND CONCLUSIONS}

In this section we shall examine the three country cases in the light of the three questions that encapsulated our evaluation.

First, we asked, 'how far were discourses of de-institutionalisation and ageing in place embraced in actual policy strategies?' In Malta, the policy of ageing in place, declared since the late 1980s, started with a short-lived hope to actually return older people from a mega institution back to community living. In fact, institutional and residential beds for older adults have still risen constantly since then. In contrast, Israel, which initiated its strategy at an earlier stage in the demographic ageing process when demand was weaker, succeeded in reducing residential beds occupied by older persons. In Spain, LAPAD aimed to provide support for dependent people to improve their quality of life and autonomy. While LAPAD did not particularly mention the greater or lesser use of institutions, it offered services like home support, daycare and assisted-living residential care. Without being an explicit goal of the law, de-institutionalisation became a clear effect (Mesa-Raya and Gracia-Romero, 2010). In the end, the benefit most implemented was the Allowance for Family Care - as a way of reducing costs, but also as a response to the growing demand (Deusdad et al., 2016b). The effect was a reduced dependence on institutions along with a re-familisation process involving an increasing care burden on female family members. In Israel, in fact, although the state provides resources for ageing, the de-institutionalisation process is partial, because not enough benefits are allocated at the community and household levels to adequately allow older adults to 'age in place' when they have no family support. No legislation aimed at de-institutionalisation has been launched in Spain or Malta, and while there is a good supply of residential beds, not all of them are publicly subsidised. While institutional care is highly valued in both countries, waiting lists severely limit the availability of such care.

The above takes us to the second question, that is, 'which older adults are given access to institutional care?' Older adults seek institutional care due to frailty, poor health and lack of family support. Our question is whether institutional care is a preferred option or, rather, a last resort amidst a rise 
in care needs and a fall in the supply of care traditionally provided by the family (see Deusdad, Javornik et al., in this volume) in the Mediterranean. We have seen that, in the three countries, inadequate resources and limited legal entitlement result in limited formal community service. In Spain this was further worsened by stringent budgets due to economic crisis, while institutionalisation is publicly funded only when older adults are severely dependent. In Malta, the growth of community resources has been slow and at times stagnant. The answer to our second question would therefore seem to be that it is not strictly only those adults who are most frail or in poorest health who enter institutional care, but largely those without adequate support for ageing in place. Lack of adequate community resources makes it impossible to ensure that institutionalisation only occurs as a matter of true need or personal choice.

The third question concerns 'to what extent have policy discourse and strategies corresponded to reality?' It is worth noting that although in all three countries we see a reduction in available family care due to rising female employment, times of crisis and austerity may sometimes reverse this order. For instance, a rise in unemployment in Spain may have led to the opposite phenomenon: an increased availability and expectation of family care, falling more often than not on women's shoulders. Thus, in the case of Spain, although institutionalisation is accepted and the different generations have become more reluctant to live together (Jensen and Møberg, 2011), austerity measures have seriously limited access to affordable residential care. As a consequence, ageing in place is made possible by the re-familisation of care (Deusdad et al., 2016b). This is less strong in the case of Malta or Israel, where no similar austerity measures followed the 2008 economic crisis. In fact, Israel differs markedly from the two other countries, in that more state resources are placed into the enabling of ageing in place.

While valued by the Charter of fundamental rights of the European Union (European Parliament, 2010), discouraging institutionalisation is not the best solution for every older adult. What is best depends on the range of services available in the community or at home, the degree of dependency and the kind of services required for the older adult. Ideally, selecting appropriate services for the older adult should derive from considerations of the best interest of that older adult (Grabowski, 2006; Mansell et al., 2007; Wysocki et al., 2015). Yet, as we can see in the three countries, issues of availability and affordability mean that it is often not the interests of the older adult upon which such selection is eventually made.

Such insufficient responses by the state to implement a deinstitutionalisation process of care for older people have facilitated the privatisation of institutional care services, even in countries with signifi- 
cant state funding, like Israel. Marketisation in these three Mediterranean countries varies from quasi-markets in Israel, through outsourcing mechanisms in all the three countries, to private-public partnerships and greater reliance on irregular employment in Spain and Malta. Where privatisation and marketisation processes result in cream-skimming of the more affluent elderly clients, this can exacerbate the social exclusion of less well-off older adults. Another result of inadequate community resources is the growing reliance in all three countries on home-based migrant care workers, mostly women, who substitute or complement family care. This bottom-up development, not initiated by policy-makers, merits further research.

Overall, as Gal (2010) indicated, regional similarities do exist. The three countries clearly share common values and approaches. While traditionally valorising a male breadwinner-female carer family model, rising female employment rates have - in the absence of adequate state resources for ageing in place - contributed to a dearth of care for older adults. Those unable to afford private care solutions, or to employ migrant carers under the counter, often enter last-resort government-subsidised institutional care after long waiting lists not by choice but for want of an alternative. These common threads suggest the existence of a common Mediterranean regime for the care of older adults.

Nevertheless, each country does have specific features. In Israel there has been a de-institutionalisation process during the last three decades, reflected in LTCIP. Yet this process is limited due to the partial assistance the LTCIP provides. In contrast to the community care provided by LTCIP, full funding by the government for institutional care is available, subject to an income test. Thus, where more supervision or assistance is required due to severe disability or illness, and the older adult and his or her family cannot afford the assistance required in the community, institutionalisation becomes the only solution.

In Malta, widespread public support for institutional care has perhaps facilitated the delayed, sketchy and somewhat stagnant development of community care alternatives. Institutionalisation might be more acceptable in Malta because, within its compact population, frequent - even daily visiting by relatives is made easy by proximity. While innovative measures are now being taken to reduce waiting lists for institutions through a public wage subsidy for carers, it will be interesting to find out whether this pilot scheme will manage to be both effective and sustainable to help meet the accelerating challenges of ageing and of female employment.

In the case of Spain, institutionalisation of older people is lower than in the two other cases, and can also be considered a false de-institutionalisation because ageing in place happens with almost no resources, which increases the care burden on the family and, above all, on women. In fact, 
paradoxically, de-institutionalisation in Spain is often the result of not having enough resources to go into care institutions, in other words, families being unable to afford it. In such circumstances, it seems that whether or not an older adult chooses to enter (or indeed to leave) an institution depends far less on his or her choice or needs, but more on the time and financial resources of relatives and the availability of adequate and affordable community services. The LTC law only helps cases assessed as higher degrees of dependence, and then only through co-payment schemes and after having been on a waiting list for a long period, so as to obtain a place on an assisted-living care home, which is publicly funded.

Though more research is needed, there is enough evidence that deinstitutionalisation, though cited as a goal in EU policy, has not been fully embraced by these three Mediterranean states. It may be argued that the three countries manifest an illusory policy of de-institutionalisation, because not enough public and community resources are invested to assure desirable and adequate conditions for ageing in place in the face of decreased autonomy in the activities of daily living or of additional challenges like dementia.

To conclude, while all three countries have attempted, to different degrees, to move away from institutional care and towards ageing in place, the reduction of the family care burden has been limited. Israel was the only country to achieve what could be called numerical de-institutionalisation a reduction of residential populations, and possibly also the most notable degree of individual de-institutionalisation - the actual move of persons back to the community. All three countries achieved a certain amount of preventive de-institutionalisation, that is, the diversion of individuals from institutional care by maintaining them in the community. In Spain, the planned growth of community support was stopped in its tracks by the economic crisis, resulting in a re-familisation process, a forced ageing in place and a false de-institutionalisation, in which the responsibility for care was not transferred to formal community services as planned, but largely back to family care - a resource that paradoxically increased due to the crisis.

\section{REFERENCES}

Angelelli, J. (2006), 'Promising models for transforming long-term care', The Gerontologist, 46 (4), 428-30.

Asiskovitch, S. (2013), 'The long-term care insurance program in Israel: solidarity with the elderly in a changing society', Israel Journal of Health Policy Research, $2(1), 3$. 
Azary-Viesel, S. and H. Stier (2014), 'Welfare budgets for Israel's elderly population', in D. Ben-David (ed.), State of the Nation Report: Society, Economy and Policy in Israel, accessed 1 November 2016 at http://taubcenter.org.i1/wp-cont ent/files_mf/e2014.15welfarebudgetsfortheelderly70.pdf.

Bachrach, L.L. (1976), 'De-institutionalisation: an analytical review and sociological perspective', DHEW Publication No. (ADM)376-51, Washington: US Government Printing Office.

Ben-Zvi, B. (1990), 'The contribution of the long-term care insurance law to the welfare of severely dependent elderly', Social Security, 2, 100-16.

Borowski, A. (2015), 'Israel's long-term care social insurance scheme after a quarter of a century', Journal of Aging and Social Policy, 27 (3), 195-14.

Borowski, A. and H. Schmid (2001), 'Israel's long-term care insurance law after a decade of implementation', Journal of Aging and Social Policy, 12 (1), 49-71.

Brodsky, J., J. Habib and M. Hirschfeld (2003), 'Long-term care strategies in industrialised countries: case studies of insurance based and non-insurance based long-term care systems', Jerusalem: Myers-JDC-Brookdale Institute and WHO NMH/CCL, accessed 28 March 2016 at http://brookdale.jdc.org.il/_Uploads/ PublicationsFiles/123-03-longtermcare-new-ES-ENG.pdf.

Brodsky, G., Y. Snoor and S. Beer (2015), 'Elderly in Israel: facts and figures', Jerusalem: Myers-JDC-Brookdale Institute.

Central Bureau of Statistics - Israel (2016a), 'Population 2015, by population group, religion, sex, age', accessed 26 October 2016 at http://www.cbs.gov.i1/rea der/shnaton/templ_shnaton_e.html?num_tab $=$ st02_03\&CYear $=2016$.

Central Bureau of Statistics - Israel (2016b), 'GDP data', accessed 28 March 2016 at http://cbs.gov.il/publications16/1633/pdf/t17.pdf.

Central Bureau of Statistics - Israel (2016c), 'Social protection expenditure', accessed 28 March 2016 at http://cbs.gov.il/shnaton66/st10_08.pdf.

Damiani, G., V. Farelli, A. Anselmi, L. Sicuro, A. Solipaca, A. Burgio, D. Iezzi and W. Ricciardi (2011), 'Patterns of long term care in 29 European countries: evidence from an exploratory study', BMC Health Services Research, 11 (316), accessed 28 February 2016 at https://www.ncbi.nlm.nih.gov/pmc/articles/ PMC3228675/.

Davey, J., G. Nana, V. de Joux and M. Arcus (2004), 'Accommodation options for older people in Aotearoa/New Zealand', Report prepared for the Centre for Housing Research Aotearoa/New Zealand (CHRANZ), Wellington, Aotearoa/ New Zealand: NZ Institute for Research on Ageing/Business \& Economic Research Ltd, accessed 28 February 2016 at https://www.beehive.govt.nz/sites/ all/files/Accomodation $\% 20$ Options $\% 20$ for $\% 20$ Older $\% 20$ People.pdf.

Deusdad, B., C. Pace and A. Anttonen (2016a), 'Facing the challenges in the development of long-term care for older people in Europe in the context of an economic crisis', Journal of Social Service Research, 42 (2), 144-50.

Deusdad, B., D. Comas-D’Argemir and S. Dziegielewski (2016b), 'Restructuring long-term care in Spain: the impact of the economic crisis on social policies and social work practice', Journal of Social Service Research, 42 (2), 246-62.

Doron, A. (ed.) (2007), Formulating Welfare Policy In Israel, 2000-2005, Jerusalem: Taub Center, accessed 1 March 2016 at http://taubcenter.org.il/for mulating-welfare-policy-israel-2000-2005/.

Doyle, M. and V. Timonen (2007), Home Care for Ageing Populations: A Comparative Analysis of Domiciliary Care in Denmark, the United States and Germany, Cheltenham, UK and Northampton, MA, USA: Edward Elgar Publishing. 
EC - European Commission, DG for Employment, Social Affairs and Equal Opportunities (2008), Report of the Ad Hoc Expert Group on the Transition from Institutional to Community-based Care, Brussels: European Commission.

EEGTICC - European Expert Group on the Transition from Institutional to Community-based Care (2012), 'Common European guidelines on the transition from institutional to community-based care', accessed 30 March 2016 at http://www.deinstitutionalisationguide.eu/wp-content/uploads/2016/04/ GUIDELINES-Final-English.pdf.

European Commission (2007), Special Barometer 283 - Health and Long-Term Care in the European Union, accessed 30 March 2016 at https://data.europa.eu/ euodp/en/data/dataset/S657_67_3_EBS283.

European Commission (2012), Long-Term Care: Need, Use and Expenditure in The EU27, accessed 30 March 2016 at http://ec.europa.eu/economy_finance/ publications/economic_paper/2012/ecp469_en.htm.

European Commission (2015), The 2015 Ageing Report, accessed 20 November 2016 at http://ec.europa.eu/economy_finance/publications/european_economy/2015/ pdf/ee3_en.pdf.

European Parliament (2010), Charter of Fundamental Rights of The European Union, accessed 15 April 2016 at http://ec.europa.eu/justice/fundamental-rights/ charter/index_en.htm.

Eurostat (2016a), Population by Five Year Age Groups and Sex, accessed 16 October 2016 at http://appsso.eurostat.ec.europa.eu/nui/show.do?dataset=demo_pjangro up\&lang=en.

Eurostat (2016b), Life Expectancy at Age 60 Data Set, accessed 28 March 2016 at http://appsso.eurostat.ec.europa.eu/nui/submitViewTableAction.do.

Eurostat (2016c), Social Protection Data Set, accessed 27 March 2016 at http:// ec.europa.eu/eurostat/web/social-protection/data/database.

Eurostat (2016d), Long-Term Care Beds in Nursing and Residential Care Facilities by NUTS 2 Regions Dataset, accessed 25 October 2016 at http://appsso.eurostat. ec.europa.eu/nui/show.do?dataset $=$ hlth_rs_bdsns\&lang $=$ en.

Fakhoury, W. and S. Priebe (2007), 'De-institutionalisation and reinstitutionalisation: major changes in the provision of mental healthcare', Psychiatry, 6 (8), 313-16.

Ferrera, M. (1996), 'The Southern model of welfare in social Europe', Journal of European Social Policy, 6, 17-37.

Gal, J. (2009), 'Is there an extended family of Mediterranean welfare states, or did Beveridge and Bismarck take the Mediterranean cruise together?', paper presented at the SPA Annual Conference, University of Edinburgh.

Gal, J. (2010), 'Is there an extended family of Mediterranean welfare states?', Journal of European Social Policy, 20 (4), 283-300.

Gal, J. and R. Pesach (2002), 'The development of the social security system for the aged in Israel and its implications', Social Security, 62, 114-41.

Goffman, E. (1968), Asylums: Essays on the Social Situation of Mental Patients and Other Inmates, New York: Doubleday.

Grabowski, D.C. (2006), 'The cost-effectiveness of noninstitutional long-term care services: review and synthesis of the most recent evidence', Medical Care Research and Review, 63 (1), 3-28.

Guillén, A.M. and M. León (ed.) (2011), The Spanish Welfare State in European Context, Farnham, UK and Burlington, USA: Ashgate.

Harnett, T. (2010), 'Seeking exemptions from nursing home routines: residents' 
everyday influence attempts and institutional order', Journal of Aging Studies, 24 (4), 292-301.

Hidalgo-Lavié, A. and M. Fernández-Sanz (2010), Trabajo social en el Ámbito de la Ley de Dependencia: Reflexiones y Sugerencias, Oleiros La Coruña: Netbiblo.

Iecovich, E. (ed.) (2003), The System of Community and Institutional Services for the Elderly, Jerusalem: JDC-ESHEL.

Iecovich, E. (2012), 'The long-term care insurance law in Israel: present and future', Journal of Aging and Social Policy, 24 (1), 77-92.

Ilinca, S., K. Leichsenring and R. Rodrigues (2015), 'From care in homes to care at home: European experiences with (de) institutionalisation in long-term care', Vienna: European Centre for Social Welfare Policy and Research, accessed 15 December 2016 at www.euro.centre.org/data/1449741582_83911.pdf.

Imserso (2014), Informe 2014. Las personas mayores en España, accessed 1 November 2016 at http://www.imserso.es/InterPresent1/groups/imserso/docu ments/binario/22029_info2014pm.pdf.

Jensen, P. and R.J. Møberg (2011), 'Tensions related to the transition of elderly care from an unpaid to a paid activity', in B. Pfau-Effinger and T. Rostgaard (eds), Care Between Work and Welfare in European Societies, Basingstoke: Palgrave Macmillan, pp. 98-114.

Kane, R.L. and R.A. Kane (2001), 'What older people want from long-term care, and how they can get it', Health Affairs, 20 (6), 114-27.

Koren, M.J. (2010), 'Person-centered care for nursing home residents: the culturechange movement', Health Affairs, 29 (2), 312-17.

Lang, G., B. Löger and A. Amann (2007), 'Well-being in the nursing home - a methodological approach towards the quality of life', Journal of Public Health, 15 (2), 109-20.

Lavee, Y. and R. Katz (2003), 'The family in Israel: between tradition and modernity', Marriage and Family Review, 35 (1-2), 193-217.

Lehmann, S. and J. Havlíková (2014), 'Predictors of the availability and variety of social care services for older adults: comparison of Central European countries', Journal of Social Service Research, 41 (1), 113-32.

Leibfried, S. (1992), 'Towards a European welfare state', in C. Jones (ed.), New Perspectives on the Welfare State in Europe, London: Routledge, pp. 133-56.

Lerman, P. (1985), 'De-institutionalisation and welfare policies', The ANNALS of the American Academy of Political and Social Science, 479 (1), 132-55.

Mansell, J., M. Knapp, J. Beadle-Brown and J. Beecham(2007), 'Deinstitutionalisation and community living - outcomes and costs: report of a European Study', Executive Summary, no. 1, accessed 30 May 2016 at https://www.kent.ac.uk/ tizard/research/research_projects/DECLOC_Volume_1_Exec_Summary.pdf.

Mathew-Puthenparambil, J. and T. Kröger (2016), 'Using private social care services in Finland: free or forced choices for older people?', Journal of Social Service Research, 42 (2), 167-79.

Mesa-Raya, C. and F. Gracia-Romero (2010), 'Mujer y atención a la dependencia en Aragón: una aportación para la consecución de la igualdad entre hombres y mujeres', Aequalitas: Revista Jurídica de Igualdad de Oportunidades entre Mujeres y Hombres, 27, 62-70.

Moise, P., M. Schwarzinger, M.-Y. Um and the Dementia Experts Group (2004), 'Dementia care in 9 OECD countries: a comparative analysis', OECD Health, Working Papers no. 13, accessed 30 September 2015 at http://www.oecd.org/ health/health-systems/33661491.pdf. 
Moreno, L. (2000), Cuidados precarios: la 'Última Red' de Protección Social, Barcelona: Ariel.

Moreno-Fuentes, F.J. and P. Mari Klose (2015), The Mediterranean Welfare Regime and the Economic Crisis, London: Routledge.

Naon, D. and N. Strosberg (1996), Changes in the Pattern of Institutionalisation of Disabled Elderly Following the Implementation of the Community Long-term Care Insurance Law, Jerusalem: The Brookdale Institute.

OECD (2016a), 'Health statistics', accessed 28 March 2016 at http://stats.oecd.org/ index.aspx? DataSetCode=HEALTH_STAT.

OECD (2016b), 'Long-term care public expenditure', accessed 28 March 2016 at http://www.oecd-ilibrary.org/social-issues-migration-health/health-at-a-glance2015/long-term-care-public-expenditure-health-and-social-components-as-shareof-gdp-2013-or-nearest-year_health_glance-2015-graph201-en.

Pace, C. (2002), 'Remodelling service for new context - a response to community mental health need in Malta', PhD thesis, University of Leicester, accessible at https://www.um.edu.mt/library/oar//handle/123456789/944.

Pace, C. (2009), 'The Maltese welfare state: hybrid wine in Rightist bottles (with Leftist labels)?', in K. Schubert, S. Hegelich and K. Bazant (eds), The Handbook of European Welfare Systems, London: Routledge, pp. 344-62.

Pace, C., S. Vella and S.F. Dziegielewski (2016), 'Long-term care of older adults in Malta: influencing factors and their social impacts amid the international financial crisis', Journal of Social Services Research, 42 (2), 263-79.

Petmesidou, M. (1996), 'Solidaridad y protección social en Grecia', Cuaderno de Trabajo, 9, 291-301.

Rabig, J., W. Thomas, R.A. Kane, L.J. Cutler and S. McAlilly (2006), 'Radical redesign of nursing homes: applying the Green House concept in Tupelo, Mississippi', The Gerontologist, 46 (4), 533-9.

Rhodes, M. (1996), 'Southern European welfare states: identity, problems and prospects for reform', South European Society and Politics, 1 (3), 1-22.

Schmid, H. (2009), 'Israel's long-term care insurance scheme', paper presented at the International Expert Meeting on Monitoring Long-Term Care for the Elderly, Hebrew University of Jerusalem, accessed 15 December 2016 at www. euro.centre.org/data/1254227500_87459.pdf.

Schmid, H. and A. Borowski (2004), 'Selected issues in the delivery of home care services to the elderly after a decade of implementing Israel's long-term care insurance law', Social Security, 7, 87-114.

Solomon, R. (2004), 'The role of the social worker in long-term care', Journal of Gerontological Social Work, 43 (2-3), 187-202.

Thomas, W.H. (2004), What are Old People for? How Elders Will Save the World, Acton: Vander Wyk \& Burnham.

Toren, N. (2003), 'Tradition and transition: family change in Israel', Gender Issues, 21 (2), 60-76.

Torrens-Bonet, R. (2012), 'La contratación de mujeres inmigrantes ¿Una alternativa a la crisis del cuidado de las personas?', Portularia, XII (extra), 221-30.

Vara, M.J. (2014), 'Long-term care for elder women in Spain: advances and limitations', Journal of Aging and Social Policy, 26 (4), 347-69.

Vilà, A. (2011), Serveis Socialis. Aspectes Històrics, Institucionals i Legislatius, Barcelona: UOC.

WHO - World Health Organization (2007), 'Global age-friendly cities: a guide', 
accessed 20 January 2017 at http://www.who.int/ageing/publications/Global_age_ friendly_cities_Guide_English.pdf?ua $=1$.

Wysocki, A., M. Butler, R.L. Kane, R.A. Kane, T. Shippee and F. Sainfort (2015), 'Long-term services and supports for older adults: A review of home and community-based services versus institutional care', Journal of Aging \& Social Policy, 27 (3), 255-79. 